\title{
IMPLEMENTASI NILAI-NILAI PANCASILA DALAM ERA "NEW NORMAL"
}

\author{
Sri Mirnawati, S.Pd \\ SMP Negeri 5 Martapura \\ *Korespodensi: sri.mirnawati75@gmail.com
}

\begin{abstract}
ABSTRACK
The Covid-19 pandemic that Indonesia has been facing since March 2020 requires well-planned handling to deal with this new normal or new normal. Adopt health protocols that are in accordance with World Health Organization (WHO) directives that apply globally to strengthen community resilience in the face of the Covid-19 pandemic. Through various policies that have been established by the Government of Indonesia to respond to this Covid-19 pandemic health disaster. The level of transmission and spread of Covid-19 is still increasing and there has not been a significant decrease because the implementation of policies that handle Covid-19 which refers to WHO directives are still faced with many problems so that the handling is still not optimal and effective. Therefore, it is necessary to change the approach to handling the Covid-19 pandemic which is based on the values of Pancasila as a view of the life philosophy of the nation and the Indonesian people when viewed from the perspective of national interests, which is expected to increase the useful results of the efforts to handle the Covid-19 pandemic carried out by the Government. The implementation of Pancasila values in handling the Covid-19 pandemic can create a new normal or a new normal that is free from Covid-19.
\end{abstract}

\begin{abstract}
ABSTRAK
Pandemi Covid-19 yang tengah dihadapi oleh Indonesia sejak Maret 2020 ini memerlukan penanganan yang terencana dengan baik untuk menghadapi new normal atau normal yang baru ini. Mengadopsi protokol kesehatan yang sesuai dengan arahan World Health Organization (WHO) yang berlaku secara global untuk memperkuat ketahanan masyarakat dalam menghadapi pandemi Covid-19. Melalui berbagai kebijakan yang telah ditetapkan Pemerintah Indonesia merespon bencana kesehatan pandemi Covid-19 ini. Tingkat penularan dan penyebaran Covid-19 ini masih terus meningkat dan belum terlihat penurunan yang signifikan dikarenakan implementasi kebijakan yang penanganan Covid-19 yang mengacu pada pada arahan WHO masih banyak dihadapkan oleh banyaknya permasalahan, sehingga masih belum optimal dan efektif pengangan yang dilakukan. Oleh karena itu, perlu adanya perubahan pendekatan penanganan pandemi Covid-19 yang berbasis nilai-nilai Pancasila sebagai pandangan falsafah hidup bangsa dan masyarakat Indonesia jika dilihat dari persepektif kepentingan nasional, yang diharapkan dapat meningkatkan hasil guna dari upaya penanganan pandemi Covid-19 yang dilakukan oleh Pemerintah. Implementasi nilai-nilai Pancasila dalam penanganan pandemi Covid-19 ini dapat memunculkan kondisi new normal atau normal baru yang

bebas dari Covid-19.
\end{abstract}

Keyword: Pancasila, Era New Normal, Pandemi, Covid-19 


\section{PENDAHULUAN}

Indonesia termasuk ke dalam pandemi Covid-19 yang melanda di dunia. Dengan melakukan kebijakan karantina di wilayah (lockdown) agar penyebaran virus ini dapat dibatasi secara total. Namun, mengubah perilaku sosial dikalangan masyarakat tidak lah mudah. Bahkan di negara-negara maju seperti di Eropa dan Amerika Serikat mengalami banyak kewalahan mengenai keterbatasan kendala yang tidak sederhana. Manusia di bumi sudah terbiasa dengan perilaku sosialnya. Kebijakan umum yang mengharuskan masyarakat untuk melakukan social and physical distancing yang mana kita harus menjaga jarak aman antara individu dengan individu lainnya ternyata bukan sesuatu yang mudah.

Kebijakan ini kemudian di modifikasi di berbagai negara dengan sedemikian rupa. Ada yang menerapkan dengan penuh, sebagian, atau lokal dan seminimal mungkin. Indonesia menerapkan modifikasi ini dengan nama Pembatasan Sosial Berskala Besar (PSBB) yang diberlakukan per wilayah, baik provinsi atau kabupaten/kota berdasarkan tingkat keparahan wabah yang dinilai oleh pemerintah pusat melalui Kementerian Kesehatan. Pelaksanaan PSBB diatur dalam Peraturan Pemerintah (PP) Nomor 21 Tahun 2020 tentang Pembatasan Sosial Berskala Besar. Selain itu aturan tentang PSBB diatur pula dalam Keputusan Presiden (Kepres) Nomor 11 Tahun 2020 mengenai penetapan kedaruratan Kesehatan Masyarakat.

Walaupun kebijakan PSBB ini tidak diberlakukan secara serentak diwilayah Indonesia, namun dampaknya terhadap sosial ekonomi masyarakat tetap terasa di seluruh Indonesia. Setelah melewati praktis selama 5 bulan masa tanggap darurat dan PSBB, pemerintah Indonesia mulai melaksanakan penerapan kehidupan normal yang baru (new normal) dan melonggarkan PSBB. Melakukan aktivitas normal sebagai bentuk perubahan perilaku dengan tetap menerapkan protokol kesehatan dalam mencegah terjadinya penularan Covid-19 merupakan kehidupan normal yang baru atau new normal. Menyesuaikan pola hidup, menata kehidupan dan perilaku baru merupakan prinsip dari new normal ini. "Empat sehat lima sempurna" dibuat pemerintah sebagai penerapan di masyarakat. Memakai masker, memelihara jarak fisik, membasuh tangan, istirahat yang cukup dan jangan panik, merupakan maksud dari empat sehat. Sebagai penyempurna yang kelima makan 
santapan yang bernutrisi untuk menuntun ketahanan atau kekebalan sistem tubuh. (Fina Surya, 2020).

Ditinjau dari sudut pandang Pancasila sebagai dasar hukum, landasan ideologi dan falsafah hidup berbangsa dan bermasyarakat, sesuai dengan pola penanganan pandemi Covid-19 di atas. Sebenarnya kebijakan sudah berjalan sesuai dengan penjabaran Pancasila, dengan sila kelima sebagai kerangka kebijakan, kerangka kerangka kelembagaan, dan kerangka implementasi dari penanganan Covid-19 oleh Pemerintah. Kerangka "new normal" termasuk usaha dalam mempersiapkan sistem kehidupan produktif dan aman dari Covid-19. Pancasila sebagai dasar negara, ideologi serta pandangan hidup bangsa dan negara, serta sebagai sumber inspirasi bagi seluruh komponen bangsa dalam mewujudkan kehidupan berbangsa dan bernegara ini sangat diperhatikan dalam penangan bencana pandemi Covid-19. Pancasila sebagai pandangan hidup bangsa yang menjadi pertimbangan utama dalam penanganan Covid-19 dan kelanjutannya menuju "new normal" untuk memulihkan kesejahteraan masyarakat yang terdampak bencana covid-19.

\section{TINJAUAN PUSTAKA}

Menurut Carl J Federick dalam teori kebijakan, mendefinisikan sebuah serangkaian tindakan atau kegiatan yang diusulkan seseorang, kelompok, maupun pemerintah dalam suatu lingkungan tertentu disebut sebagai kebijakan dimana terdapat hambatanhambatan (kesulitankesulitan). (Leo Agustino, 2008). Interaksi antara dua pihak atau lebih bisa mendapatkan tingkat komunikasi yang dihadapkan pada elemen kerja sama dan kepercayaan sesuai dengan teori sinergitas menurut A.F Stones James dalam Soekanto. Guna mencapai tujuan bersama maka dilakukannya suatu pekerjaan. Teori pemberdayaan ini teori terakhir dimana kata pemberdayaan berkaitan dengan penggalian dan pengembangan potensi masyarakat menurut Kartasasmita (1996). Setiap manusia yaitu masyarakat memiliki potensi yang dapat dikembangkan, dengan begitu pemberdayaan merupakan cara untuk membangun daya tersebut serta dapat mengembangkannya dengan upaya mendorong, memberikan motivasi dan membangkitkan kesadaran akan potensi yang dimiliki. 
Dalam pemberdayaan, berbagai upaya pembangunan tidak menjadikan masyarakat sebagai obyek melainkan subyek, dimana pemberdayaan harus mengikuti pendekatan: (1) harus terarah (targeted), (2) harus langsung mengikutsertakan atau bahkan dilaksanakan oleh masyarakat yang menjadi sasaran, dan (3) menggunakan pendekatan kelompok.

\section{METODE}

Metode deskriptif kualitatif adalah metode penelitian yang digunakan dalam tulisan ini. Dengan menggunakan jenis penelitian kepustakaan (library research), metode pengumpulan data pustaka, membaca, dan mencatat serta mengolah bahan penelitian sangat berkaitan dimana penelitian pustaka merupakan serangkaian kegiatan (Zed, 2004). Penulis menggunakan pendekatan analisis isi (content analysis) sebagai penghimpun informasi yang relevan terkait dengan topik atau masalah pada tulisan ini.

Penulis juga melakukan teknik pengumpulan data yang akan dipecahkan melalui studi penelaahan terhadap buku - buku, literatur - literatur, dan laporan - laporan yang ada hubungannya dengan masalah ini. Setelah data terkumpul maka barulah dianalisis berbagai bacaan, baik dari sisi kelebihan, kekurangan, maupun keterkaitan tentang tulisan yang dibahas dari setiap temuan yang ditemukan. Memberikan ulasan kritis dengan mengelaborasi model maupun pendekatan yang berbeda dari temuan dalam artikel sebelumnya merupakan tahap terakhir dalam metode penelitian ini. Sehingga penelitian ini dapat berjalan dengan baik.

\section{HASIL PEMBAHASAN}

Dunia saat ini sedang disibukkan dengan urusan sebuah pandemi, Indonesia pun tidak terhindari. Adanya pandemi ini disebabkan oleh sebuah virus yang berakibat kematian dengan dipicu oleh adanya flu, batuk, dan sesak nafas. Virus ini pertama kali di temukan di kota Wuhan Cina. Virus ini bernama Corona atau lebih tepatnya yaitu Covid-19 (Coronavirus Disease 2019). Virus ini telah merenggut warga Cina yang menjadi tempat awal adanya virus ini dengan ribuan nyawa secara beruntun. (Lin et al, 2020). 3 bulan lamanya Pemerintah mengisolasi kota Wuhan 
agar kemudian tidak dapat dimasuki oleh warga lain. Pemerintah juga melarang warga Wuhan untuk meninggalkan tempat tinggalnya sampai penyakit ini hilang secara permanen.

Bagi masyarakat Indoneisa wabah ini sangat memberikan dampak psikis. Banyaknya jumlah korban selalu dihadirkan disetiap berita yang ada di statiun televisi. Pemberitaan sifat virus yang sangat mudah sekali menyerang dan menular ke manusia bahkan dapat bertahan hidup beberapa saat dibenda nonmanusia ini membuat warga semakin ketakuan. Hasil survei Radio Republik Indonesia (RRI) yang dikabar kan oleh wartawan melalui surat kabar online (Yahya, 2020) menunjukkan tingginya tingkat kekhawatiran masyarakat terhadap COVID-19 yakni mencapai 68 persen bersama dengan lembaga survei Indo Barometer.

Asep Saepudin seorang peneliti Indo Barometer mengungkapkan bahwa dengan adanya berbagai berita yang menyatakan bahwa penularan virus ini sangat mudah, dapat menyebabkan kematian, dan belum ada obatnya membuat masyarakat yang kurang pengetahuan mengeluarkan banyak kecemasan. Lin et al. (2020) memiliki pendapat tersendiri untuk menanggapi fenomena Covid-19 dengan menilai sisi menarik yang dimiliki kasus ini. Adanya pandemi sejenis yang menimpa London pada 1981 seolah publik diingatkan kembali dengan kehadiran Covid-19 saat ini. Diantara keduanya yang memiliki kesamaan yakni menyebabkan kematian banyak orang yang dimulai dari sakit dibarengi dengan flu. Perpanjangan waktu libur yang diadakan atau istirahat untuk semua warga, dilakukannya lockdown di berbagai kota, hingga banyak tersedianya akses perawatan intensif khusus hingga isolasi pasien dari jangkauan public, menjadikan dampak dari kedua wabah tersebut juga serupa. Pernyataan Lin et al. (2020) jika dicermati sesungguhnya terkandung cacatan penting yang dapat kita jadikan sebagai pengetahuan jika terjadi kasus penyakit serupa dimasa depan. Bahwa kelak akan terjadi wabah besar yang menyerang ke seluruh penjuru dunia dan ribuan orang tewas karena adanya gejala flu ini menjadi ciri-ciri tersendiri. Semua ini merupakan sinyal bahwa dunia akan dilanda marabahaya. Terlebih jika setelah kejadian tersebut disertai dengan adanya pengambilan keputusan untuk meliburkan para pekerja dalam waktu yang panjang atau adanya perintah untuk lockdown dari pemerintah. 
Upaya pencegahan dan pengendalian pandemi Covid-19 terus dilakukan Indonesia hingga saat ini, begitu pula dengan negaranegara lain di dunia. Jumlah kasus COVID-19 di Indonesis terus bertambah. Meskipun sebagian dapat sembuh, tapi tidak sedikit yang meninggal. Berdasarkan pemaparan tersebut salah satu upaya yang dilakukan dalam mewujudkan hal tersebut yaitu dengan diberlakukannya Era New Normal atau normal yang baru. Kenormalan baru yang diberlakukan pemerintah ini bertujuan agar masyarakat yang ingin keluar rumah karena hal yang penting dapat berhati-hati dan lebih disiplin di masa pandemi seperti saat ini. Tentunya upaya yang dilakukan oleh pemerintah dan masyarakat ini agar kita dapat menjalankan aktivitas sehari-hari beriringan dengan pandemi yang terjadi saat ini. Sebelum menuju kepada kehidupan normal baru atau "new normal" pastinya kita mengalamami keadaan darurat. Tentunya keadaan darurat ini sangat berbeda dengan keadaan normal, ternyata terdapat beberapa pandangan dari kalangan ahli hukum maupun politik jika kita mengkaji lebih jauh, dimana pada prinsipnya ada kesepakatan bahwa keadaan darurat adalah suatu penyimpangan siginifikan dari keadaan normal, hal ini bisa terjadi karena dipicu oleh peristiwa ekstrim yang sangat menggangu atau mengancam ketertiban yang mapan. (Suryono, 2020). Dengan itu maka supaya dapat mengenali keadaan darurat ini harus adanya latar belakang keadaan yang normal sesuai yang disampaikan oleh (La Ode Muhaimin, 2020).

Istilah yang akhir-akhir ini sering dibicarakan tidak lain adalah Era new normal atau kenormalan baru. Kenormalan baru ini telah disiapkan dengan baik scenarionya oleh kementerian koordinasi bidang perekonomian dan direncanakan mulai sejak 1 Juni. Menjaga jarak dari rekan kerja lainnya merupakan awal dari perencanaan, lalu dilanjutkan dengan mengenakan pakaian khusus kerja, pengukuran suhu pada saat memasuki pintu masuk, dan memakai masker merupakan protokol kesehatan yang telah dioperasikan oleh industri dan jasa. Penerapan Pembatasan Sosial Berskala Besar (PSBB) ini telah dilaksanakan sejak beberapa bulan terakhir dengan Pemerintah Indonesia yang siap memutar kembali roda ekonomi sebagaimana yang telah diungkapan oleh bapak Presiden Joko Widodo bahwa sampai nanti ditemukannya vaksin yang efektif masyarakat Indonesia harus hidup berdamai dengan Covid-19. Kebijakan ini lah awal mula dikenalnya istilah "new normal". (Darajati, 2020). Saat ini vaksin juga sudah mulai dilaksanakan dengan cara 
bertahap mulai dari Pemerintah, masyarakat lanjut usia, para guru, ulama, pekerja kesehatan dan sebagainya hingga sampai bagiannya masyarakat biasa tiba.

Pengertian new normal dilihat secara konseptual menurut Pemerintah Republik Indonesia yaitu beradaptasi dengan COVID-19 dengan tatanan yang baru. Sejalan dengan itu new normal dapat diartikan juga sebagai perubahan perilaku dimana masyarakat bisa untuk menjalankan aktivitas normal kesehariannya namun tetap dengan menerapkan protokol kesehatan dengan tujuan untuk mencegah terjadinya penularan Covid-19 yang masih terus meningkat hingga saat ini. (Endang Komara, 2020). Maka sesuai dengan hal-hal yang sudah dikemukakan di atas bahwa untuk memaksimalkan peran serta dari semua pihak harus beradaptasi dengan pola hidup normal baru atau new normal lifestyle. Tidak hanya masyarakat biasa tetapi juga Pemerintah pusat, pemerintah daerah, maupun swasta serta seluruh dunia kerja dan elemen masyarakat di wilayah Negara Kesatuan Republik Indonesia. Pencegahan dan pengendalian Covid-19 ini dilakukan bersamasama dan saling berkontribusi. Setiap orang (individu) atau masyarakat sangat perlu untuk memahami hal mendasar tentang fenomena Covid-19 tersebut dengan melalui diskusi dan pembelajaran sekurangkurangnya untuk dapat melaksanakan atau mengamalkan Panduan (Protokol) New Normal dari Pemerintah dengan semaksimal mungkin.

Tantangan yang harus dihadapi pada saat new normal yaitu Imunitas tubuh yang ada pada fondasi kebudayaan. Agar imunitas tubuh tatap baik masyarakat harus lebih rileks dan lebih tenang. Mekanisme kultur sangat dibutuhkan agar masyarakat siap menghadapi new normal. New Normal ini bisa disebut juga peradaban baru. Tidak lagi adanya normal yang lama tetapi beradaptasi secara alami. Makna yang sangat berarti bagi kehidupan bernegara adalah Pancasila dimana Pancasila memiliki arti "Lima Dasar". Pancasila merupakan ideologi dan pandangan hidup bangsa Indonesia yang memberikan dasar filosofi, dan nilainilai bagi kita semua. Makna dari silasila Pancasila ini dapat kita renungkan konteks nya dalam pandemi virus corona saat ini. Pancasila dalam rumusan sila-silanya telah memberikan nilai-nilai yang mendasar terkait konsep Tuhan, alam, dan manusia secara utuh dan komprehensif. (Widiyanti, 2020). 
Pemahaman Pancasila sebagai dasar negara dan pandangan hidup dalam berbangsa dan bernegara diperlukan untuk membahas lebih jauh mengenai peranan Pancasila dalam kelanjutannya menuju new normal dikehidupan yang produktif yang aman dari Covid-19. Wakil kepala Badan Pembinaan Ideologi Pancasila (BPIP) (Hariyono Mei, 2020) di Lemhannas RI. Disarikan bahwa bentuk energi positif yang menjadi sumber inspirasi dalam kehidupan berbangsa dan bernegara merupakan hasil dari pandangan hidup dari nilai-nilai Pancasila. Baik secara struktural maupun kultural nilai-nilainya dilembagakan. Berarti perlu dilibatkannya peran dan tanggung jawab dari pemerintah maupun masyarakat. Selain itu, peran Pancasila sebagai landasan ideologi dikemukakan juga sebagai landasan berpikir, sebagaimana yang dikemukakan oleh Hariyono (2020) disebut sebagai progessive thinking, termasuk dalam pengambilan keputusan dan penyatuan pandangan dengan memberikan kesempatan memperluas kreativitas, inovasi, dan lokal jenius yang berbasis kerjasama (kolaborasi) diantara pihak yang terlibat. Pancasila juga ditegaskan dapat dijadikan common platform diantara pihak-pihak yang terlibat. Pancasila juga memiliki peranan penting yang mana dalam mempersatukan berbagai keberagaman penting yang ada. Oleh karena itu, Pancasila dalam implementasinya sebagai dasar ideologi dan pandangan hidup perlu dipertimbangkan adanya keberagaman atau kemajemukan dalam konteks sosial budaya. Sebagai salah satu yang perlu dijadikan modal sosial budaya di tingkat masyarakat madani (civil society) (Hariyono, Mei 2020).

Professor Azumardi Azra di Lemhannas RI juga menjelaskan terkait dengan Rehabilitasi dan Rejuvenus Pancasila (Azra, Mei 2020). Beberapa aspek pokok dalam perwujudan Pancasila yang lebih kontekstual dan aktual dengan memerlukan penjabaran Pancasila, sehingga Pancasila dapat dijadikan kekuatan pemersatu (integrating force) sebagai prinsip dasar jati diri bangsa, yang dihadapkan pada tantangan krisis identitas budaya pada situasi keragaman budaya (multi culture), sebagaimana sejalan dengan Profesor Hariyono untuk menjadi common platform yang mana di dalam implementasinya menjadi ideologi terbuka ini membutuhkan keterbukaan dari Pancasila (Azra, Mei 2020). 
Pancasila sangatlah relevan dengan protokol penanganan Covid-19 dan kesiapan menuju new normal dengan merujuk gambar 1 diatas. Terlebih dengan memperhatikan fungsi Pancasila sebagai dasar negara, landasan ideologi, dan falsafah hidup berbangsa dan bernegara serta bermasyarakat yang apabila dikaitkan dengan aktualisasinya dalam kondisi kekinian khususnya dalam menuju kehidupan yang produktif yang aman dari Covid-19. Sudah sepatutnya bahwa kesiapan menuju new normal ini didasarkan oleh Pancasila. Dari sini Pancasila dapat dijadikan dasar dalam penetapan strategi dan kebijakan untuk mempersiapkan kehidupan yang produktif aman dari Covid-19 atau new normal yang menjadi landasan sebagai upaya pemulihan kondisi dan masyarakat yang terdampak pandemi Covid-19.

Dapat disimpulkan bahwa masing-masing sila dalam Pancasila dapat dijadikan sebagai prinsip dasar atau protokol dalam penanganan Covid-19 dan persiapan menuju new normal. Dapat diaktualisasikan berikut ini yaitu pada (1) sila ketuhanan, tidak hanya menerapkan dari sisi agama tetapi juga diarahkan untuk terwujudnya peningkatan kedisiplinan. Terwujudnya kondisi masyarakat produktif dan aman dari pandemi Covid-19 ini sebagai prasyarat. (2) dalam sila kemanusiaan ini untuk meningkatkan sistem kesehatan masyarakat yang mana membangun masyarakat secara totalitas dalam kehidupan berbangsa dan bernegara menjadi prasyaratnya. (3) sila persatuan disini lah mewujudkan kebersamaan (integrating force) untuk melawan Covid-19 sebagaimana telah diimplementasikan melalui gerakan "Bersama Lawan Covid" (BLC). (4) dalam sila kerakyatan ini memprioritaskan suara dan aspirasi rakyat dengan mengedepankan prinsip penanganan Covid-19 dan persiapan menuju new normal khususnya bagi msyarakat yang terdampak Covid-19. (5) dan yang terakhir sila keadilan, disini untuk dapat menjangkau masyarakat korban pandemi Covid-19 yang proporsional dan berasaskan keadilan sosial dengan mengupayakan perluasan perlindungan sosial dan bantuan sosial.

Terkait dengan proses alur pikir yang melatarbelakangi, maka diperlukan penjabaran nilainilai Pancasila untuk menuju kehidupan produktif yang aman dari Covid-19 (new normal). Masing-masing sila sebagai falsafah dan pandangan hidup ini dijabarkan aktualisasinya dalam penanganan Covid-19 sebagai implikasi kesiapan untuk menuju new normal. Matriks aktualisasi 
secara terperinci mencoba menjabarkan masing-masing sila dari Pancasila mulai dari perwujudan dan aktualisasinya hingga implikasinya untuk menuju kehidupan normal baru, yang mana untuk menjadikan Pancasila sebagai prinsip dasar atau protokol, dengan penjelasan: (1) sila pertama, mendorong implementasi dari moderasi beragama, khususnya ada pembatasan kegiatan ibadah, yang dimana memerlukan kedisiplinan dalam penerapan pembatasan sosial berskala besar, khususnya di daerah terdampak parah (zona merah). (2) sila kedua, melalui peningkatan sistem kesehatan berbasis masyarakat, yang diimplementasikan melalui 4 sehat 5 sempurna (social distancing, memakai masker, cuci tangan dengan air dan sabun, istirahat yang mencukupi, serta asupan makanan bergizi). (3) sila ketiga, melakukan desentralisasi penanganan ke tingkat daerah dan desa, terutama dalam penetapan pembatasan sosial berskala besar dalam lingkup ekonomi informal dan KUKM yang terdampak, melalui penerapan jaring pengaman sosial (social safety net). (4) sila keempat, melibatkan peran serta masyarakat dan pelaku kepentingan lainnya, dengan memprioritaskan suara dan aspirasi masyarakat, terutama yang berada di wilayah terdampak atau potensial terdampak, untuk dapat lebih mandiri di dalam memitigasi risiko penyebaran Covid-19 dan terakhir (5) sila kelima mengupayakan perluasanjangkauan perlindungan sosial dan bantuan sosial, khususnya kepada masyarakat yang terdampak Covid-19, termasuk mengupayakan pemulihan krisis ekonomi bagi sektor yang terdampak.

\section{KESIMPULAN}

Dengan tetap konsisten mengacu pada Pancasila sebagai dasar negara, landasan ideologi, dan pandangan hidup dalam berbangsa, bernegara, dan bermasyarakat, maka dengan itu seharusnya upaya mempersiapkan kondisi kehidupan pasca Covid-19 yang tetap produktif dan aman dari Covid-19 (new normal life) yang dilakukan oleh Pemerintah dan seluruh komponen bangsa dapat dilakukan secara lebih baik dan terarah. Untuk itu, juga diperlukan pemahaman yang utuh terhadap nilai-nilai Pancasila yang terkandung di setiap silanya, agar dapat diaktualisasikan dalam kondisi permasalahan bangsa. Terutama dalam merespon dan menghadapi isu dari dua permasalahan yang dihadapi bangsa Indonesia saat ini, yaitu mempersiapkan kehidupan normal 
baru yang tetap produktif dan aman. Pemerintah selama ini telah mencoba menerapkan prinsip dasar atau protokol yang berlaku global seperti yang telah ditetapkan oleh World Health Organization (WHO). Walaupun kinerjanya sudah cukup baik, tapi tetap memerlukan penyempurnaan untuk dapat mempercepat penanganan pandemi Covid-19 ini secara lebih membuahkan hasil.

\section{SARAN DAN UCAPAN TERIMAKASIH}

Maka, diperlukannya upaya yang lebih memperhatikan nilai-nilai luhur bangsa Indonesia yang telah dituangkan ke dalam Pancasila sebagai dasar negara, landasan ideologi, dan falsafah hidup bangsa Indonesia, yang dapat dijadikan prinsip dasar untuk keberlanjutannya menuju kehidupan normal baru yang produktif dan aman dari Covid-19.

\section{DAFTAR PUSTAKA}

Azra, Asyumardi. 2020. Materi Ceramah PPRA LXI, Lemhannas RI.

Anggraeni, Fina S., Erfendi. 2020. Implementasi Merdeka Belajar Di Era New Normal dan

Paradigma Konstruktivisme. International Conference on Islamic and Social Education Interdisciplinary, 1(1), 278-290.

Darajati, M. R. 2020. Covid-19 : Indonesia New Normal, dan Sebuah Pembealajaran. Artikel : Lintas Pakar.

Endang Komara. 2020. Adaftasi kenormalan baru dalam pespektif sosial budaya,makalah webinar.

Gugus Tugas Nasional Covid-19. 2020. Laporan Situasi Harian Percepatan Penanganan Covid 19 (30 Mei 2020).

Hadi, Suprayoga. 2020. Implementasi Nilai Pancasila dalam Perencanaan Percepatan Penanganan dan Pemulihan Terdampak Pandemi Covid-19. Majalah Media Perencana

Perkumpulan Perencana Pembangunan Indonesia, 1(1), 23-24.

Hariyono. 2020. Materi Ceramah PPRA LXI, Lemhannas RI. 
Hassan Suryono. 2020. Politik Hukum Membumikan Karakter Nilai Nilai Pancasila Dalam

Menghadapi Masa New Normal Covid 19. Journal Pendidikan Sosial.

Kartasasmita Ginanjar. 1996. Pembangunan untuk Rakyat Memadukan Pertumbuhan dan Pemerataan. PT. Pustaka Cidesindo: Jakarta.

Kepres Nomor 11 Tahun 2020 Tentang penetapan kedaruratan kesehatan masyarakat covid-19.

Lemhannas RI. 2020. Bahan Ajar Bidang Studi EMPAT KONSENSUS DASAR BANGSA, Sub Bidang Studi PANCASILA.

La ode Muhaimin, 2020.New normal dalam perspektif hubungan pusat - daerah makalah webinar Tahun 2020.

Muhyiddin. 2020. Covid-19, New Normal, Perencanaan Pembangunan Di Indonesia. The Indonesian Journal of Development Planning, 4(2), 246-247.

Peraturan pemerintah No. 21 Tahun 2020 Tentang pembatasan sosial berskala besar dalam rangka percepatan penanganan corona virus disease (covid-19) ditetapkan di jakarta pada tanggal 31 maret Tahun 2020 oleh presiden Joko Widodo.

Widiyanti Rahma Ayu. 2020. Implementasi Nilai-Nilai Dasar Pancasila Dalam dan Pasca Covid 19 Demi Menyongsong Era Adaptasi Kebiasaan Baru (AKB). Journal Pendidikan Sosial Keberagaman, 7(2), 136-140.

Zed, M. (2004). Metode Penelitian Kepustakaan. Jakarta: Yayasan Obor Indo. 